Int. J. Dev. Biol. 58: 1-8 (2014)

doi: $10.1387 / \mathrm{ijdb} .130323 \mathrm{mw}$

\title{
Sox7 in vascular development: review, insights and potential mechanisms
}

\author{
JEANETTE J. WAT ${ }^{1}$ and MARGARET J. WAT*,2 \\ ${ }^{1}$ Department of Chemical Sciences, Rice University, and ${ }^{2}$ Department of Molecular and Human Genetics, \\ Baylor College of Medicine, Houston, Texas, USA
}

\begin{abstract}
Cardiovascular development is crucial to the survival of higher organisms, integrally transporting oxygen and nutrients and in later life, facilitating immune function. Only in recent years has the molecular basis of the formation of this ancient conduit system been explored. While transcription factors are essential to specify and differentiate core cellular and structural components of the developing heart and vessels, only a subset of these essential factors are currently known. A transcription factor of emerging importance in the cardiovascular system is Sox7, a member of the F group of Sox genes, as Sox7 removal in recent animal and cellular studies has resulted in disruptions of cardiovascular development. However, the molecular mechanisms of Sox 7 action have largely remained obscure. In this paper, we first review the highly conserved and robust cardiovascular expression pattern of Sox 7 across multiple species. We then provide evidence of a compelling role for Sox7 in vascular development, elucidating major pathways in which Sox 7 functions, including VEGF/Flk1 signaling, Wnt signaling, and Notch pathway. Furthermore, we propose mechanisms connecting all of these important developmental pathways through Sox7, in a way not previously postulated in the developing vascular system. The emerging picture reveals Sox7 as an important developmental gene that connects other vascular regulators and that has significance in human disease.
\end{abstract}

KEY WORDS: Sox7, Wnt signaling, vascular development, Notch pathway, expression pattern

\section{Introduction}

Proper development of the cardiovascular system is vital to higher organisms. Perturbations in this system can lead to devastating diseases, including congenital heart disease, the number one cause of infant morbidity, and vessel abnormalities that contribute to disorders ranging from tumor formation to retinal diseases. While the anatomy and physiology of many cardiovascular malformations have been well-characterized, only in the past decade have the genetic underpinnings of these abnormalities begun to be explored using vertebrate and invertebrate model organisms. Thoroughly characterizing these molecular pathways has important implications in understanding normal heart and vessel development as well as in facilitating therapies for cardiovascular disease.

Thus far, the majority of genes identified in congenital heart diseases encode transcription factors such as Gata4 and Nkx2.5. Many of these cardiac- and vascular- relevant transcription factors function in major developmental pathways. Emerging evidence suggests that the Soxfamily - in particular the SoxFsubfamily of Sox7, Sox17, and Sox18-directs normal cardiovascular development.
The Sox gene family (Sry-related HMG box gene family) encodes transcription factors containing a common $\sim 80$ amino acid HMG DNA binding domain, which is closely related to the HMG box in the founding member SRY (Gubbay et al., 1990). There are ten subgroups of SOX proteins (A-J) (Bowles et al., 2000). SOX proteins are important in embryonic development and in cell fate determination (Pevny and Lovell-Badge, 1997; Avilion et al., 2003). Sox7 belongs to the subgroup F, along with Sox17 and Sox18. Sox17has been shown to be involved in cardiac and hematopoietic development in addition to definitive endoderm development (Liu et al., 2007; Kanai-Azuma et al., 2002; Sakamoto et al., 2007). Sox18 is important in blood vessel and lymphatic development in mice.

There is evidence of conservation of sequence, expression, and function among SoxF family genes. SoxF proteins share a very similar primary structure with greater than $80 \%$ amino acid

\footnotetext{
Abbreviations used in this paper: BMP, bone morphogenetic protein; CXCR4, chemokine (C-X-C motif) receptor 4; GATA4, GATA Binding Protein 4; Nkx2.5, NK2 homeobox 5; SDF1, stromal cell-derived factor; Sox, Sry-related HMG box; SRY, sex determining region Y; VEGF, vascular endothelial growth factor.
}

*Address correspondence to: Margaret J. Wat. Baylor College of Medicine, One Baylor Plaza, Houston, TX, 77030, USA. Tel: +1-832-712-6218.

E-mail: margaretwat7@gmail.com 


\section{J.J. Wat and M.J. Wat}

identity within the HMG domain (Bowles et al., 2000). SoxF subgroup members in Drosophila and vertebrates also share highly conserved intronic positions, which represent ancient introns present before vertebrate lineage divergence (Bowles et al., 2000; Kanai et al., 1996; Taniguchi et al., 1999). Expression of mouse Sox18 across embryonic and adult tissue Northern blot analyses occurs in a very similar pattern to that of Sox7; furthermore, Sox7, Sox17, and Sox18 each colocalize to the developing mouse embryonic vasculature (Takash et al., 2001; Young et al., 2006). Functionally, Sox 7 and Sox 17 can also activate Sox18 targets and modify the Sox18 mutant mouse phenotype (Hosking et al., 2009).

Sox17/- mouse mutants have defects in heart looping, cardiac bifida, and impaired cardiac mesoderm differentiation (Liu et al., 2007; Pfister et al., 2011; Sakamoto etal., 2007). Mutations in SOXF genes have also been reported in human diseases: SOX18 mutations cause hypotrichosis-lymphedema-telangiectasia syndrome, a congenital condition characterized by dilated veins, varicosities, and capillaries underneath transparent skin, and SOX17mutations have been found in some cases of primary lymphedema (Francois et al., 2008; Irrthum et al., 2003). These findings indicate that SOXF proteins are critical for normal cardiovascular development.

Here, we review Sox7 in the developing cardiovascular system by its expression pattern, detailed across mouse, human, zebrafish, and Xenopus species, and tumor tissues in Table 1, and animal

TABLE 1

\section{SOX7 EXPRESSION IN MOUSE, HUMAN, ZEBRAFISH, AND XENOPUS DURING DEVELOPMENTAL AND ADULT STAGES}

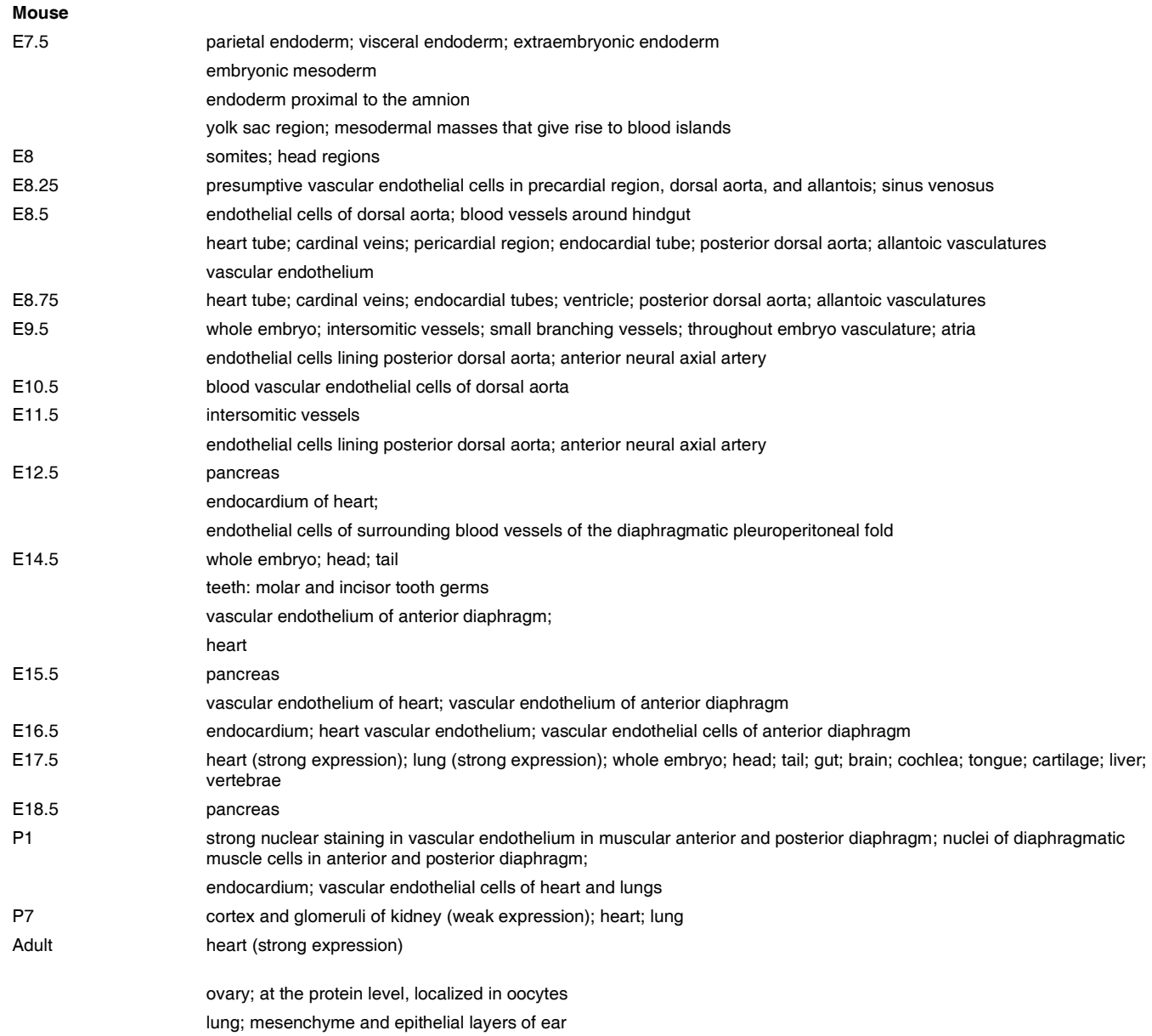

parietal endoderm; visceral endoderm; extraembryonic endoderm embryonic mesoderm endoderm proximal to the amnion

yolk sac region; mesodermal masses that give rise to blood islands somites; head regions

presumptive vascular endothelial cells in precardial region, dorsal aorta, and allantois; sinus venosus endothelial cells of dorsal aorta; blood vessels around hindgut

heart tube; cardinal veins; pericardial region; endocardial tube; posterior dorsal aorta; allantoic vasculatures vascular endothelium

heart tube; cardinal veins; endocardial tubes; ventricle; posterior dorsal aorta; allantoic vasculatures

whole embryo; intersomitic vessels; small branching vessels; throughout embryo vasculature; atria endothelial cells lining posterior dorsal aorta; anterior neural axial artery

blood vascular endothelial cells of dorsal aorta

intersomitic vessels

endothelial cells lining posterior dorsal aorta; anterior neural axial artery

pancreas

endocardium of heart;

endothelial cells of surrounding blood vessels of the diaphragmatic pleuroperitoneal fold

whole embryo; head; tail

teeth: molar and incisor tooth germs

vascular endothelium of anterior diaphragm:

heart

pancreas

vascular endothelium of heart; vascular endothelium of anterior diaphragm

endocardium; heart vascular endothelium; vascular endothelial cells of anterior diaphragm

heart (strong expression); lung (strong expression); whole embryo; head; tail; gut; brain; cochlea; tongue; cartilage; liver; vertebrae

pancreas

strong nuclear staining in vascular endothelium in muscular anterior and posterior diaphragm; nuclei of diaphragmatic muscle cells in anterior and posterior diaphragm;

endocardium; vascular endothelial cells of heart and lungs

cortex and glomeruli of kidney (weak expression); heart; lung

heart (strong expression)

ovary; at the protein level, localized in oocytes

lung; mesenchyme and epithelial layers of ear

heart; lung; brain; tongue; liver; vertebrae

lung

heart

heart, especially in ventricles, interventricular septum, and apex; lung

mesenchyme and epithelial layers of colon

trachea; lymph node; placenta; prostate

upregulated in pancreatic, gastric, and esophageal cancer cell lines; downregulated ${ }^{\mathrm{a}}$ in primary kidney, lung, prostate, breast, and colorectal tumors
Kanai-Azuma et al. 2002; Murakami et al. 2004

Murakami et al. 2004

Tam et al. 2004

Gandillet et al. 2009

Takash et al. 2001

Sakamoto et al. 2007

Matsui et al. 2006

Sakamoto et al. 2007

Tam et al. 2004

Sakamoto et al. 2007

Takash et al. 2001

Young et al. 2006

Hosking et al. 2009

Takash et al. 2001

Young et al. 2006

Lioubinski et al. 2003

Wat et al. 2012

Takash et al. 2001

Stock et al. 1996

Wat et al. 2012

Lioubinski et al. 2003; Wilson et al. 2005

Wat et al. 2012

Wat et al. 2012

Takash et al. 2001

Lioubinski et al. 2003

Wat et al. 2012

Matsui et al. 2006

Taniguchi et al. 1999; Takash et al. 2001;

Matsui et al. 2006

Taniguchi et al. 1999

Takash et al. 2001

Takash et al. 2001

Takash et al. 2001; Katoh, 2002

Katoh, 2002

Takash et al. 2001; Katoh, 2002

Takash et al. 2001

Katoh, 2002

Katoh, 2002; Guo et al. 2008; Yamamoto and Yamamoto, 2008; Wiech et al. 2009; Zhang et al. 2009 
TABLE 1 (CONTINUATION)

\section{SOX7 EXPRESSION IN MOUSE, HUMAN, ZEBRAFISH, AND XENOPUS DURING DEVELOPMENTAL AND ADULT STAGES}

\begin{tabular}{|c|c|c|}
\hline Developmental stage & Structure/location of Sox7 expression & Reference \\
\hline \multicolumn{3}{|l|}{ Zebrafish } \\
\hline Bud stage & bistripes corresponding to the posterior lateral plate mesoderm (PLM) & Pendeville et al. 2008 \\
\hline 4-somite stage & PLM & Cermenati et al. 2008 \\
\hline 5 -somite stage & extends along PLM; anterior lateral plate mesoderm (ALM) & Pendeville et al. 2008 \\
\hline 8-somite stage & PLM; innermost fli1-positive cells in the PLM; ALM & Cermenati et al. 2008 \\
\hline 18-somite stage & head; presumptive axial vessels & Pendeville et al. 2008 \\
\hline 22-somite stage & developing dorsal aorta; posterior cardinal vein; intermediate cell mass (ICM) & Cermenati et al. 2008 \\
\hline $12 \mathrm{hpf}$ & localized to lateral mesoderm & Herpers et al. 2008 \\
\hline $18 \mathrm{hpf}$ & cord-like structure (future dorsal aorta and posterior cardinal vein); presumptive migrating angioblasts & Herpers et al. 2008 \\
\hline $24 \mathrm{hpf}$ & $\begin{array}{l}\text { dorsal aorta; posterior cardinal vein; ICM; intersomitic vessels; otic vessels; vasculature of head, trunk, and tail; dorsal } \\
\text { aorta; two stripes in hindbrain }\end{array}$ & Cermenati et al. 2008; Pendeville et al. 2008 \\
\hline $26 \mathrm{hpf}$ & endothelial cells of main axial vessels, head vessels, and intersegmental vessels; two rhombomeres & Herpers et al. 2008 \\
\hline \multicolumn{3}{|c|}{ Xenopus (Xenopus laevis unless otherwise noted) } \\
\hline $\begin{array}{l}\text { Early stage embryos } \\
\text { (blastula) }\end{array}$ & generalized; eggs; oocytes & Fawcett and Klymkowsky, 2004 \\
\hline Stage $8 / 9$ embryos & localized to vegetal hemisphere & Zhang et al. 2005 a \\
\hline Stage $10 / 11$ embryos & dorsal marginal zone/Spemann Organizer; lateral marginal zones & Zhang et al. $2005 \mathrm{~b}$ \\
\hline Stage 14 embryos & ciliated cells of epidermis & Fawcett and Klymkowsky, 2004 \\
\hline Stage $16 / 17$ embryos & anterior dorsal region; anterior ventral region & Zhang et al. $2005 \mathrm{~b}$ \\
\hline Stage $24-27$ embryos & $\begin{array}{l}\text { endocardium; procardiac tube; posterior cardinal veins; aortic arch; vitelline veins; embryonic vasculature; hindbrain; } \\
\text { epidermal ciliated cells; dorsal aspect of neural tube }\end{array}$ & Fawcett and Klymkowsky, 2004 \\
\hline Stage $33 / 34$ larvae & $\begin{array}{l}\text { posterior cardinal veins; aortic arches; branching intersomitic arteries; hindbrain; stomodeal depression; epithelial straps; } \\
\text { olfactory pit; notochord; ciliated cells; posterior rhombomeres; outer edges of rhombencephalon }\end{array}$ & Fawcett and Klymkowsky, 2004 \\
\hline $\begin{array}{l}\text { Stage } 33 / 34 \\
(X . \text { Tropicalis })\end{array}$ & posterior cardinal veins; pronephric sinus; ciliated cells; central nervous system; olfactory pit; pharyngeal arches & Kyuno et al. 2008 \\
\hline Stage 40 larvae (3 dpf) & aortic arch; hindbrain; lateral edges of rhombomere 5 & Fawcett and Klymkowsky, 2004 \\
\hline Adult & lung; ovary; testis; kidney; brain; spleen & Shiozawa et al. 1996 \\
\hline
\end{tabular}

${ }^{a}$ In some tumors, such as colorectal and prostate, Sox7 down-regulation was partly due to hypermethylation at its promoter (Guo et al., 2008; Zhang et al., 2009).

studies and molecular mechanisms. Furthermore, we connect Sox 7 to important developmental networks of genes in putative mechanisms of Sox7 action (Fig. 1).

\section{A conserved role for Sox7 in cardiovascular tissues: Sox7expression in tissues of developing \& adult mouse, human, zebrafish, \& Xenopus}

Throughout the developing cardiovascular system across species, Sox 7 has a specific and prominent role as evidenced by expression studies showing its high expression level and restriction to early precursor tissues and progenitors of the vasculature and heart (Table 1).

In mouse embryos at 7.5 days post coitum (dpc), Sox 7 is expressed in the parietal and visceral endoderm, the extraembryonic endoderm, the endoderm proximal to the amnion, and the embryonic mesoderm, though not in the definitive endoderm (Kanai-Azuma et al., 2002; Murakami et al., 2004; Tam et al., 2004; Table 1).

Interestingly, at $7.5 \mathrm{dpc}, \mathrm{SOX} 7$ is also expressed in the yolk sac region and the mesodermal masses that give rise to blood islands (Gandillet et al., 2009). Around this stage (7.0-7.5 dpc), the cardiac mesoderm and foregut endoderm also migrate anteriorly and condense into the cardiac crescent. At around 7.5 to $8.0 \mathrm{dpc}$ in mouse development, yolk sac blood islands appear, and the yolk sac vasculature and paired dorsal aortae form from the lateral mesoderm. Also at this stage, groups of hemangioblasts formed from embryonic mesodermal cells are found distributed throughout the embryo and will become incorporated into the developing embryonic vasculature.

Sox7 is found expressed in the somites and head regions at 8 dpc (Takash et al., 2001). At $8.25 \mathrm{dpc}$, Sox7 expression is found in the presumptive vascular endothelial cells in the precardial region, the dorsal aorta, the sinus venosus, which would become the future atria, and the allantois (Sakamoto et al., 2007). At this point in mouse development, the linear heart tube has been formed after the left and right cardiac primordia have fused.

By $8.5 \mathrm{dpc}$, Sox7 is highly expressed in the heart tube, posterior dorsal aorta, vascular endothelium, cardinal veins, pericardial region, endocardial tube, endothelial cells of the dorsal aorta and blood vessels around the hindgut, though not in the hindgut endoderm (Tam et al., 2004; Matsui et al., 2006; Sakamoto et al., 2007). At this stage, the linear heart tube begins looping morphogenesis, and the interventricular sulcus is present. Also at this stage, angioblasts aggregate and the primitive vascular network is formed, circulation begins, intraembryonic vitelline vessels link to yolk sac vessels, and umbilical vessels link to placenta. Sox7 is also expressed in the allantoic vasculatures at $8.5 \mathrm{dpc}$ (Sakamoto et al., 2007), when the allantois extends from the embryo's posterior end and contacts the chorion. Sox7 expression continues in the heart tube, cardinal veins, posterior dorsal aorta, allantoic vasculatures, and developing ventricle at $8.75 \mathrm{dpc}$ (Sakamoto et al., 2007).

At $9.5 \mathrm{dpc}$ and $11.5 \mathrm{dpc}$, Sox 7 is expressed in the intersomitic vessels and endothelial cells lining the posterior dorsal aorta and in the anterior neural medial axial artery (Young et al., 2006; Takash et al., 2001). At $9.5 \mathrm{dpc}$, Sox7 expression is also found in small branching vessels, throughout the embryonic vasculature, 
and in the atria (Takash et al., 2001). Around this time, the mouse heart approaches the adult form. At $10.5 \mathrm{dpc}$, SOX7 is robustly expressed in the blood vascular endothelial cells of the dorsal aorta, but not in lymphatic endothelial precursors, indicating that SOX7 is not normally involved in establishing the early lymphatic vasculature (Hosking et al., 2009). Sox7 expression is found in the mouse pancreas at 12.5, 15.5, and $18.5 \mathrm{dpc}$ (Lioubinski et al., 2003; Wilson et al., 2005).

In later stages of mouse development, Sox7 can be found in other organs derived from the mesoderm and endoderm, with the strongest expression in the heart and the lungs persisting to postnatal stages. From 12.5 to $17.5 \mathrm{dpc}$, Sox 7 is expressed in a variety of organs, with strongest expression in the vascular endothelium, endocardium, heart, and lung (Wat et al., 2012; Takash et al., 2001; Stock et al., 1996). At postnatal stages, Sox7 is highly expressed in heart, lung, and vascular endothelium of diaphragm, lung, and heart, while barely expressed in the postnatal liver (Wat et al., 2012; Matsui et al., 2006; Takash et al., 2001); the high endothelial expression indicates possible involvement in regulating transcription of other vascular-relevant genes. In the adult mouse, Sox7 also has high expression in mesenchyme and epithelial layers of the ear and oocytes (Taniguchi et al., 1999; Takash et al., 2001).

In humans, expression begins in heart and lung during the embryo and persists in the adult. SOX7 is expressed in the heart, lung, brain, tongue, vertebrae, and liver of the 8-week human embryo (Takash et al., 2001). SOX7 expression in the heart and lung continued in the fetus (Katoh, 2002; Takash et al., 2001), and in the adult SOX7 is present in the heart, lung, trachea, lymph node, placenta, prostate, and the mesenchyme and epithelial layers of the colon (Takash et al., 2001; Katoh, 2002). Importantly, in the adult heart, SOX7 is more highly expressed in the ventricles, interventricular septum, and apex than in the atria (Katoh, 2002).

In zebrafish, no sox7 expression is detected prior to the end of gastrulation (Pendeville et al., 2008; Cermenati et al., 2008), but becomes expressed in the posterior lateral plate mesoderm by bud and 4-somite stages. As development continued, sox7 is expressed in the anterior lateral plate mesoderm, and then in the presumptive axial vessels coalescing into the dorsal aorta, axial vein, and posterior cardinal vein (Cermenati et al., 2008; Pendeville et al., 2008; Herpers et al., 2008). At the time circulation begins, sox 7 is expressed in the head, trunk and tail vasculature, dorsal aorta, intersomitic vessels, intermediate cell mass containing endothelial and blood cell precursors (Pendeville et al., 2008). By 1.5 days post-fertilization (dpf), sox 7 expression peaks at the time the vascular tree undergoes active remodeling.

In Xenopus laevis early stage blastula embryos, sox7 is expressed in the eggs and oocytes, and in stage 8/9 embryos, sox 7 is localized to the vegetal hemisphere (Fawcett and Klymkowsky, 2004; Zhang et al., 2005a). In gastrula stage 10/11 embryos, sox7 is expressed in the dorsal marginal zone/Spemann Organizer and lateral marginal zones (Zhang et al., 2005 b). Stage 24-27 embryos shows strong sox 7 expression in the endocardium, procardiac tube, aortic arch, posterior cardinal veins, vitelline veins, embryonic vasculature, hindbrain, epidermal ciliated cells, and dorsal aspect of neural tube (Fawcett and Klymkowsky, 2004). At stage 33/34 larvae, sox7 expression continues in the posterior cardinal veins, aortic arches, branching intersomitic arteries, hindbrain, and ciliated cells, and is also found in the stomodeal depression, epithelial straps, olfactory pit, notochord, posterior rhomomeres, and outer edges of rhombencephalon (Fawcett and Klymkowsky, 2004). In Xenopus tropicalis stage 33/34, sox7 is expressed in the posterior cardinal veins, the pronephric sinus, ciliated cells, central nervous system, olfactory pit, and pharyngeal arches (Kyuno et al., 2008). By stage 40 larvae, or $3 \mathrm{dpf}$, sox 7 expression in most of the vascular endothelia, particularly the posterior cardinal veins, has disappeared; however, sox 7 is still expressed in the aortic arch, hindbrain, and lateral edges of rhombomere 5 (Fawcett and Klymkowsky, 2004). In adult Xenopus laevis, sox7 expression is found in the lung, ovary, testis, kidney, brain, and spleen.

Detailed expression of Sox7over developmental time in mouse, human, zebrafish, Xenopus, and tumor tissues, is presented in Table 1. Sox7 appears to be predominantly expressed in the early developing cardiovascular system across species. The expression across embryonic development points to a critical role in certain systems, such as the vasculature, which is likely conserved across different species.

\section{SOX7 expression in tumor tissues and cell lines}

Human SOX7 mRNA and/or SOX7 protein is up-regulated in pancreatic, gastric, and esophageal cancer cell lines, and downregulated in primary kidney, lung, prostate, breast, and colorectal tumors (Katoh, 2002; Guo et al., 2008; Yamamoto and Yamamoto, 2008; Wiech et al., 2009; Zhang et al., 2009; Table 1). In some tumors, such as colorectal and prostate, SOX7 down-regulation is partly due to hypermethylation at its promoter (Guo et al., 2008; Zhang et al., 2009). Sox7 expression and activity changes may modulate Wnt- $\beta$-catenin-stimulated transcription and $\beta$-catenin activity in vivo and in cancers. Mouse Sox7 has been shown to repress $\beta$-catenin-mediated activation of a Tcf reporter (Takash et al., 2001). SOX7 has been shown to physically interact with and deplete active $\beta$-catenin to suppress $\beta$-catenin-mediated transcription, and restoring SOX7 antagonizes Wnt signaling and induces colorectal cancer cell apoptosis (Guo et al., 2008; Zhang et al., 2009).

\section{SOX7 in vascular development and integration of Vegf signaling, Wnt signaling, VE cadherin, and Notch path- ways}

The expression pattern of Sox7 in the major and branching arteries and veins -including vascular endothelial cells, intersomitic vessels, axial vessels, vitelline veins, aortic arches, and posterior cardinal veins - of developing mouse, zebrafish, and Xenopus (Table 1, and discussed above) indicates a specific role for Sox7 in vascular development. The lateral plate mesoderm, in which Sox 7 is expressed, gives rise to both the blood vessels and heart. Moreover, the visceral endoderm and yolk sac, which also have Sox7 expression (Table 1), have an active role in inducing and organizing the underlying vasculature development through production of vascular endothelial growth factor (VEGF), a key ligand for vessel development.

Blocking Sox7 and Sox18 by morpholinos leads to notable vascular defects in arteriovenous morphogenesis and multiple fusions between the major axial vessels (Pendeville et al., 2008; Cermenati et al., 2008). Proximal aorta dysmorphogenesis and arteriovenous shunts result in lack of circulation in the trunk and tail of double-knockdown Sox7 and Sox18 morphants, which leads to pericardial edema and subsequent embryo death (Herpers et al., 
2008; Pendeville et al., 2008; Cermenati et al., 2008). Anomalous intersomitic branching is also observed (Cermenati et al., 2008). These studies utilized zebrafish, a good model for in vivo developmental studies due to availability of molecular markers (Lo et al., 2011).

In addition to animal models, molecular studies show connections of Sox7 to important vascular markers. The proposed mechanisms of Sox7's function in the vasculature are summarized in Fig. 1. Another important vascular marker is Flk-1, the major receptor for VEGF, which is critical for vasculogenesis and early hematopoiesis, and is a marker of hemangioblasts, the common precursors of endothelial and hematopoietic cells. Flk1 expression in mouse embryos has been observed in the dorsal aorta, intersomitic vessels, endocardium, yolk-sac vasculature, and base of the allantois (Shalaby et al., 1995), locations also of Sox7 expression (see Table, and discussed above). In fact, Sox7 shows perfect colocalization with Flk1 in endothelial precursors of the presumptive dorsal aorta and in those that later contribute to axial vein formation (Pendeville et al., 2008). Flk1/- embryos die in utero between 8.5 and $9.5 \mathrm{dpc}$; interestingly, Flk1-null homozygotes phenotypically resemble to the Sox7-null homozygotes, with complete absence of yolk-sac blood islands and of organized blood vessels in yolk sacs and embryos (Shalaby et al., 1995); Sox $7^{-/}$embryos fail to remodel yolk sac vasculature and exhibit abnormal intersomitic vessel remodeling (Wat et al., 2011, 2012).

SOX7 has been proposed as a potent activator in the endothelial differentiation of Flk-1+ cells (Yamauchi et al., 2007). Importantly, in the Flk1 $1^{+}$population, the vasculogenic Sox 7 transcription factor is significantly up-regulated, overlapping with the emergence of the cardiac transcription factors Nkx2.5 and Gata4 (Nelson et al., 2009). Notably, sorting the parental Flk-1+ pool using the CXCR4/ Flk-1 biomarker pair, which is a predictor of the beginning of heart cell specification among pluripotent stem cells, reveals a divergent Sox7 expression, with significantly lower Sox7 expression in the cardiogenic subpopulation compared with the subpopulation enriched for endothelial and smooth muscle markers of vasculogenesis (Nelson et al., 2009). Thus, differential Sox7 expression may be a potential regulatory switch in deciding between cardiac and vascular pathways in Flk1+ multi-lineage precursors (Nelson et al., 2009).

Wnt/ $\beta$-catenin appears to be a key signaling cascade that integrates the Sox $F$ family, including Sox7, with the cardiovascular VEGF/FIk-1 and SDF1/CXCR4 pathways (Nelson et al., 2009). $W n t / \beta$-catenin signaling displays biphasic and opposite effects on vascular and cardiac fate selection depending on developmental stage (Naito et al., 2006). Activation of the pathway early in embryoid body formation promotes cardiomyocyte differentiation but late activation inhibits cardiomyogenesis and rather promotes hematopoietic/vascular marker expression (Naito et al., 2006). Ueno et al., (2007) also describe biphasic effect of Wnt/ $\beta$-catenin signaling in zebrafish embryos and mouse ES cells, with cardiogenic promotion if expressed early but inhibition if expressed later. Wnt/ $\beta$-catenin clearly influenced cardiogenesis, with opposing effects depending on developmental timing (Naito et al., 2006; Ueno et al., 2007).

In addition, Wntand Frizzledgenes are differentially expressed in Flk $1^{+}$cells from mouse ES cells: non-canonical Wnt-5a and Wnt-11 has significantly higher expression in Flk1 ${ }^{+}$cells compared to Flk1 ${ }^{-}$ cells, while expression of canonical Wnt-3ais reduced in Flk1 ${ }^{+}$cells (Kim et al., 2008). Fzd5, believed to be the non-canonical Wnt-5a receptor and essential for yolk sac and placental angiogenesis, is strongly detected in Flk1 ${ }^{+}$cells but not in Flk1- cells; Fzd7, involved in non-canonical Wnt signaling, also has robust expression in Flk1 ${ }^{+}$cells but not in Flk1 ${ }^{-}$cells (Kim et al., 2008). Such differential expression may be related to the differential roles of canonical and non-canonical Wnt signaling in vascular development and

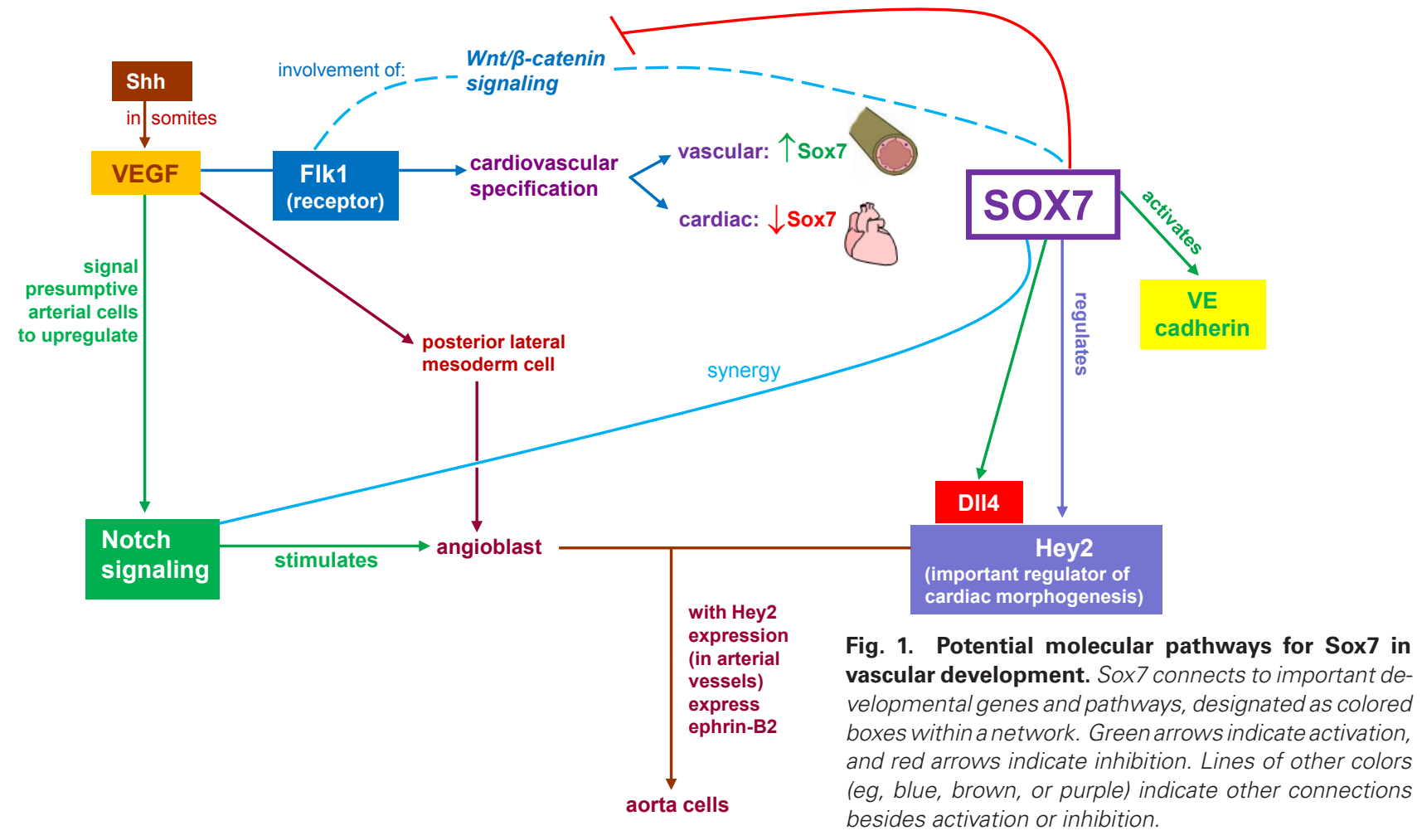


cardiogenesis. The available evidence indicates noncanonical Wnt signaling plays a key role in vasculature development.

While non-canonical Wnt signaling seems to have a role in vascular endothelial fate determination, canonical Wnt/ $\beta$-catenin signaling appears to be particularly down-regulated in the vascular system (Nacher et al., 2005; Kim et al., 2008). Xenopus sox7 has been shown to induce non-canonical wnt-11 by acting indirectly through Nodal-related xnr2 (Zhang et al., 2005 b). Wnt-11 induces cardiogenesis through activating non-canonical Wnt signaling; non-canonical Wnt signaling, similar to SOX7, has been shown to repress the canonical Wnt signaling pathway (Maye et al., 2004; Takash etal., 2001). Inhibition of Wnt//3-catenin signaling plays a role in inducing cardiogenic mesoderm (Marvin et al., 2001). Moreover, in Xenopus, the sox7 C-terminal domain that physically interacts with $\beta$-catenin is necessary to modulate $n k x 2.5$ and other cardiac gene transcription (Zhang et al., 2005 b). These findings suggest that Sox7control of multi-lineage cardiovascular differentiation may potentially be through the $\mathrm{Wnt} / \beta$-catenin axis.

sox7 is also important in establishing proper arteriovenous identity (Herpers et al., 2008; Pendeville et al., 2008; Cermenati et al., 2008). In double-knockdown sox7 and sox18 morphants, the only endothelial cell marker affected is $f l k 1$, which has a slight reduction in expression (Pendeville et al., 2008). However, expression of gridlock/hey2, an artery marker, is totally abolished in the aorta of double morphants, with higher doses of sox 7 morpholino significantly expanding the vein at the artery's expense (Pendeville et al., 2008). Furthermore, hey2 and sox $7 /$ sox 18 morphants have strikingly similar phenotypes (Pendeville et al., 2008). These findings indicated that the sox $7 /$ sox 18 morphant phenotype likely result from inhibition of hey2 expression (Pendeville et al., 2008). Sox7 has been suggested to act upstream of and activate hey2, possibly synergizing with a factor specific in the dorsal aorta, or with a component of the Notch signaling pathway (Pendeville et al., 2008). Indeed, hey2 has been shown to be important in arteriovenous specification and dependent on Notch signaling (Zhong et al., 2001). During arterial-venous differentiation, Sonichedgehog (Shh) induces expression of Vegf in somites, which signal presumptive arterial cells to upregulate Notch signaling. Notch signaling controls specification of angioblasts to either arteries or veins: Notch activation in angioblast membranes leads to activation of Gridlock, which activates ephrin-B2 and other arterial markers, while low Gridlock levels in angioblasts leads to EphB4 expression and vein formation (Zhong et al., 2001; Lawson et al., 2002; Fig. 1). Arterial DIl4 expression is also decreased with the ablation of the Sox motif in the DIl4 enhancer-transgene expression in mice (Sacilotto et al., 2013). Knockdown of sox7, sox18, and rbpj in zebrafish leads to loss of endogenous dll4 expression and disappearance of both arterial markers and a dorsal aorta (Sacilotto et al., 2013).

Hey2 mediates Notch signaling in the developing cardiovascular system. Hey proteins have been shown to depend on, and be downstream targets of, Notch signaling. Nakagawa et al., has demonstrated that the intracellular domain of the Notch-1 receptor upregulates Hey2 in fibroblasts (Nakagawa et al., 2000). In cultured arterial smooth muscle cells, Hey2 has been found to be a direct target of Notch signaling (Iso et al., 2002), suggesting a role for HEY2 in the cardiovascular system as a transcriptional repressor downstream of Notch signaling. In zebrafish, a Notch-Hey2 pathway appears to control the first embryonic artery assembly in arteriovenous specification (Zhong et al., 2001). In addition, HEY proteins appear to repress their own expression through interference with Notch signaling (Nakagawa et al., 2000). In somites, Hey genes exhibit a periodic expression (Nakagawa et al., 1999), similar to Notch signaling-related molecules.

Hey genes are expressed in vascular precursors from the earliest developmental stages. In addition to its connection to Sox7 in zebrafish as described above, Hey2-an important artery marker - is strongly expressed in allantois (which harbors large numbers of vascular precursor cells), dorsal aorta, aortic arch arteries, vasculature (including the smooth muscle layer), and developing kidney vasculature in the mouse (Nakagawa et al., 1999), having an expression pattern similar to that of Sox7 (Table 1). Moreover, Hey2 vascular expression is lower at $15.5 \mathrm{dpc}$ than at $10.5 \mathrm{dpc}$ (Nakagawa et al., 1999). As discussed earlier, Sox7 vascular expression in the mouse is also primarily in earlier stages, such as prior to 12.5 $\mathrm{dpc}$; indeed, Sox7 expression in most of the vascular endothelia, particularly the posterior cardinal veins, had disappeared by stage 40 larvae of Xenopus (Table 1). In the developing vasculature at around 8.5 and $9.5 \mathrm{dpc}$ in the mouse, SOX7 expression is limited to the endothelial cells of the vasculature and the heart endocardial cells (Wat et al., 2011).

Hey2 mutant mice exhibit disrupted vascular development. Combined loss of Hey2 and Hey 1 results in embryonic death after $9.5 \mathrm{dpc}$ with a global lack of vascular remodeling and massive hemorrhage (Fischer et al., 2004). In addition, yolk sac vasculature is disorganized and embryonic developing major vessels are small or absent, similar to the Sox7 mutants which lack blood vessel remodeling in the yolk sac (Wat et al., 2012). Also, both Hey2 and Hey1 expression in yolk sacs of Notch1 knockouts are strongly reduced (Fischer et al., 2004). Decreased vascular flow in the Sox $7^{-}$mutants is observed between E8.5 and E9.5, and Sox $7^{-1}$ embryos have abnormal angiogenesis and vascular remodeling, with the vasculature appearing disordered and supernumerary (Wat et al., 2011).

Another role for Sox7 in endothelial development comes from results showing that enforced SOX7 expression in mouse hemangioblast colonies sustains the expression of endothelial markers (Costa et al., 2012). SOX7 binds and activates the promoter of VE-cadherin, demonstrating that VE-cadherin is a downstream transcriptional target of SOX7 (Costa et al., 2012). These results indicate that SOX7 transcriptionally regulates genes expressed in the hemogenic endothelium (Costa et al., 2012). Furthermore, Sox7 knockdown results in a strong reduction in embryonic stem (ES) cell ability to form endothelial colonies (Gandillet et al., 2009).

Sox7s connection to the Flk1/VEGF pathway and Wnt and Notch signaling as discussed above, implicate it as a key regulator in this process. Taken together, all these findings point to a role of Sox7 in a VEGF-Flk1-Notch-Hey2 pathway, potentially through involvement with Wnt/ $\beta$-catenin signaling, for vascular development. The connections between these pathways are displayed in Fig. 1.

\section{Mesoderm to endoderm connections: implications of Sox7's role in the vasculature on development of other organs}

Signaling between mesoderm and the anterior visceral endoderm is necessary for proper cardiac induction. Mesoderm-endoderm signaling is also important in the development of several other structures: for example, in addition to endodermal specification 
of cardiogenic mesoderm, mesodermal derivatives can induce the endodermal tube to produce the rudiments of some digestive organs. This, along with the Sox7 expression patterns discussed earlier, yields an interesting connection. Specification and formation of the liver particularly requires the gut endoderm to be exposed to both cardiogenic mesoderm and blood vessel endothelial cells; meanwhile, pancreas formation needs activation by the notochord and blood vessels (Lammert et al., 2003; Deutsch et al., 2001). Mouse aortic endothelium recombined with isolated dorsal endoderm leads to endocrine pancreatic differentiation; conversely, removal of dorsal aortic endothelial precursors in frog embryos abolishes endocrine pancreas gene expression, demonstrating the critical role of endothelium in pancreatic development (Lammert et al., 2001). Similarly, hepatic epithelium from mice lacking endothelial cells fails to undergo proper morphogenesis (Matsumoto et al., 2001). Interestingly, as seen in the Table, Sox7 is expressed in both the cardiac and vascular endothelial structures, and also in all three of the above structures: pancreas, liver, and notochord, as well as the gut. It has been proposed that signaling molecules, such as certain BMP, Wnt, TGF-beta, and PDGF family members from endothelial cells, play an important role in organ formation (Lammert et al., 2003). Sox 7 may control the transcription of signaling molecules which control development of these organs.

\section{Conclusions}

In this review, we have presented a comprehensive overview of Sox7, revealing its role as a key regulator of significant transcription factors, signaling molecules, and pathways involved in vascular and cardiac development, with connections to other organs as well. The expression patterns observed across species demonstrate a very early and specific role for Sox 7 in cardiovascular development. Indeed, this role has been confirmed in both invertebrate and vertebrate animal models, with zebrafish morphants exhibiting features of cardiovascular failure strikingly similar to those observed in Sox7 mutant mice. Moreover, Sox7's expression in cardiogenic mesoderm and blood vessel endothelium also suggests involvement in mesoderm to endoderm signaling and organ development. The major pathways discussed in the vasculature include VEGF-FIk1, Wnt, and Notch. Mechanistically, Sox7s role in arterial differentiation and endothelial development, and its molecular interactions with the Wnt/ $\beta$-catenin, VEGF-FIk1, and Notch pathways, situates it as a key regulator within a network of important vasculature development genes. As there are clearly similarities within the SoxFgroup, it would be interesting to further elucidate how Sox 7 interfaces with its highly homologous family members, Sox 17 and Sox 18. Clearly, understanding more of Sox7 promises to expand our knowledge of the complex workings underlying cardiovascular development across species. Collectively, these connections reveal that Sox 7 stands at the intersection of vital biological pathways and processes, which crosstalk in mediating vascular formation and organogenesis.

\section{Acknowledgments}

The authors would like to thank Dr. David McClay for reviewing and providing valuable comments on this review.

\section{References}

AVILION AA, NICOLIS SK, PEVNY LH, PEREZ L, VIVIAN N, LOVELL-BADGE R (2003). Multipotent cell lineages in early mouse development depend on SOX2 function. Genes Dev 17: 126-140.

BOWLES J, SCHEPERS G, KOOPMAN P (2000). Phylogeny of the SOX family of developmental transcription factors based on sequence and structural indicators. Dev Biol 227: 239-255

COSTAG, MAZANA, GANDILLETA, PEARSONS, LACAUD G, KOUSKOFFV (2012). SOX7 regulates the expression of VE-cadherin in the haemogenic endothelium at the onset of haematopoietic development. Development 139: 1587-1598.

CERMENATI S, MOLERI S, CIMBRO S, CORTI P, DEL GIACCO L, AMODEO R, DEJANA E, KOOPMAN P, COTELLI F, BELTRAME M (2008). Sox18 and Sox7 play redundant roles in vascular development. Blood 111: 2657-2666.

DEUTSCH G, JUNG J, ZHENG M, LÓRA J, ZARET KS (2001). A bipotential precursor population for pancreas and liver within the embryonic endoderm. Development 128: 871-881.

FAWCETT SR, KLYMKOWSKY MW (2004). Embryonic expression of Xenopus laevis SOX7. Gene Expr Patterns 4: 29-33.

FISCHER A, SCHUMACHER N, MAIER M, SENDTNER M, GESSLER M (2004). The Notch target genes Hey1 and Hey2 are required for embryonic vascular development. Genes Dev 18: 901-911.

FRANCOIS M, CAPRINI A, HOSKING B, ORSENIGO F, WILHELM D, BROWNE C, PAAVONEN K, KARNEZIS T, SHAYAN R, DOWNES M, DAVIDSON T, TUTT D, CHEAH KS, STACKER SA, MUSCAT GE, ACHEN MG, DEJANA E, KOOPMAN $P$ (2008). Sox18 induces development of the lymphatic vasculature in mice. Nature 456: 643-647.

GANDILLETA, SERRANOAG, PEARSONS, LIE-A-LING M, LACAUD G, KOUSKOFF $V(2009)$. Sox7-sustained expression alters the balance between proliferation and differentiation of hematopoietic progenitors at the onset of blood specification. Blood 114: 4813-4822.

GUBBAYJ, COLLIGNONJ, KOOPMANP, CAPELB, ECONOMOUA, MÜNSTERBERG A, VIVIAN N, GOODFELLOW P, LOVELL-BADGE R (1990). A gene mapping to the sex-determining region of the mouse $Y$ chromosome is a member of a novel family of embryonically expressed genes. Nature 346: 245-250.

GUO L, ZHONG D, LAU S, LIU X, DONG XY, SUN X, YANG VW, VERTINO PM, MORENO CS, VARMA V, DONG JT, ZHOU W (2008). Sox7 Is an independent checkpoint for beta-catenin function in prostate and colon epithelial cells. $\mathrm{Mol}$ Cancer Res 6: 1421-1430.

HERPERS R, VAN DE KAMP E, DUCKERS HJ, SCHULTE-MERKER S (2008). Redundant roles for sox7 and sox18 in arteriovenous specification in zebrafish. Circ Res 102: 12-15.

HOSKING B, FRANÇOIS M, WILHELM D, ORSENIGO F, CAPRINI A, SVINGEN T, TUTT D, DAVIDSON T, BROWNE C, DEJANA E, KOOPMAN P (2009). Sox7 and Sox17 are strain-specific modifiers of the lymphangiogenic defects caused by Sox18 dysfunction in mice. Development 136: 2385-2391.

IRRTHUM A, DEVRIENDT K, CHITAYAT D, MATTHIJS G, GLADE C, STEIJLEN PM, FRYNS JP, VAN STEENSEL MA, VIKKULA M (2003). Mutations in the transcription factor gene SOX18 underlie recessive and dominant forms of hypotrichosislymphedema-telangiectasia. Am J Hum Genet 72: 1470-1478.

ISO T, CHUNG G, HAMAMORI Y, KEDES L (2002). HERP1 is a cell type-specific primary target of Notch. J Biol Chem 277: 6598-6607.

KANAI Y, KANAI-AZUMAM, NOCE T, SAIDO TC, SHIROSHI T, HAYASHI Y, YAZAKI K. (1996). Identification of two Sox17 messenger RNA isoforms, with and without the high mobility group box region, and their differential expression in mouse spermatogenesis. J Cell Biol 133, 667-681.

KANAI-AZUMA M, KANAI Y, GAD JM, TAJIMA Y, TAYA C, KUROHMARU M, SANAI Y, YONEKAWA H, YAZAKI K, TAM PP, HAYASHI Y(2002). Depletion of definitive gut endoderm in Sox17-null mutant mice. Development 129: 2367-2379.

KATOH M (2002). Expression of human SOX7 in normal tissues and tumors. Int $J$ Mol Med 9: 363-368.

KIM DJ, PARK CS, YOON JK, SONG WK (2008). Differential expression of the Wnt and Frizzled genes in Flk1+ cells derived from mouse ES cells. Cell Biochem Funct 26: 24-32.

KYUNO J, MASSÉ K, JONES EA (2008). A functional screen for genes involved in Xenopus pronephros development. Mech Dev 125: 571-586.

LAMMERT E, CLEAVER O, MELTON D (2001). Induction of pancreatic differentiation by signals from blood vessels. Science 294: 564-567.

LAMMERT E, CLEAVER O, MELTON D (2003). Role of endothelial cells in early pancreas and liver development. Mech Dev 120: 59-64. 
LAWSON ND, VOGEL AM, WEINSTEIN BM (2002). Sonic hedgehog and vascular endothelial growth factor act upstream of the Notch pathway during arterial endothelial differentiation. Dev Cell 3: 127-136.

LIOUBINSKI O, MÜLLER M, WEGNER M, SANDER M (2003). Expression of Sox transcription factors in the developing mouse pancreas. Dev Dyn 227: 402-408.

LIUY, ASAKURAM, INOUE H, NAKAMURAT, SANOM, NIUZ, CHENM, SCHWARTZ RJ, SCHNEIDER MD (2007). Sox17 is essential for the specification of cardiac mesoderm in embryonic stem cells. Proc Natl Acad Sci USA 104: 3859-3864.

LO KH, HUI MN, YU RM, WU RS, CHENG SH (2011). Hypoxia impairs primordial germ cell migration in zebrafish (Danio rerio) embryos. PLoS One 6: E24540.

MARVIN MJ, DI ROCCO G, GARDINER A, BUSH SM, LASSAR AB (2001). Inhibition of Wnt activity induces heart formation from posterior mesoderm. Genes Dev 15: 316-327.

MATSUI T, KANAI-AZUMA M, HARA K, MATOBA S, HIRAMATSU R, KAWAKAMI $\mathrm{H}$, KUROHMARU M, KOOPMAN P, KANAI Y (2006). Redundant roles of Sox17 and Sox18 in postnatal angiogenesis in mice. J Cell Sci 119: 3513-3526.

MATSUMOTOK, YOSHITOMI H, ROSSANT J, ZARETK (2001). Liver Organogenesis Promoted by Endothelial Cells Prior to Vascular Function. Science 294: 559-563.

MAYE P, ZHENG J, LI L, WU D (2004). Multiple mechanisms for Wnt11-mediated repression of the canonical Wnt signaling pathway. J Biol Chem279:24659-24665.

MURAKAMI A, SHEN H, ISHIDA S, DICKSON C (2004). SOX7 and GATA-4 are competitive activators of Fgf-3 transcription. J Biol Chem 279: 28564-28573.

NACHER V, CARRETERO A, NAVARRO M, ARMENGOL C, LLOMBART C, BLASI J, RUBERTE J (2005). beta-Catenin expression during vascular development and degeneration of avian mesonephros. J Anat 206: 165-174.

NAITOAT, SHIOJIMAI, AKAZAWAH, HIDAKAK, MORISAKIT, KIKUCHIA, KOMUROI (2006). Developmental stage-specific biphasic roles of Wnt/beta-catenin signaling in cardiomyogenesis and hematopoiesis. Proc NatlAcad SciUSA 103: 19812-19817.

NAKAGAWA O, MCFADDEN DG, NAKAGAWA M, YANAGISAWA H, HU T, SRIVASTAVA D, OLSON EN (2000). Members of the HRT family of basic helix-loop-helix proteins act as transcriptional repressors downstream of Notch signaling. Proc Natl Acad Sci USA 97: 13655-13660.

NAKAGAWA O, NAKAGAWA M, RICHARDSON JA, OLSON EN, SRIVASTAVA D (1999). HRT1, HRT2, and HRT3: a new subclass of bHLH transcription factors marking specific cardiac, somitic, and pharyngeal arch segments. Dev Biol216: 72-84.

NELSON TJ, CHIRIAC A, FAUSTINO RS, CRESPO-DIAZ RJ, BEHFAR A, TERZIC $A(2009)$. Lineage specification of Flk-1+ progenitors is associated with divergent Sox7 expression in cardiopoiesis. Differentiation 77: 248-255.

PENDEVILLE H, WINANDY M, MANFROID I, NIVELLES O, MOTTE P, PASQUE V, PEERS B, STRUMAN I, MARTIAL JA, VOZ ML (2008). Zebrafish Sox7 and Sox18 function together to control arterial-venous identity. Dev Bio/317: 405-416.

PEVNY LH, LOVELL-BADGE R (1997). Sox genes find their feet. Curr Opin Genet Dev 7: 338-344.

PFISTER S, JONES V, POWER M, GERMAINE T, KHOO PL, STEINER K, KANAIAZUMA M, KANAIY, TAM PP, LOEBELD (2011). Sox17-dependent gene expression and early heart and gut development in Sox17-deficient mouse embryos. Int J Dev Biol 55: 45-58.

SACILOTTO N, MONTEIRO R, FRITZSCHE M, BECKER PW, SANCHEZ-DELCAMPO L, LIUK, PINHEIRO P, RATNAYAKAI, DAVIESB, GODING CR, PATIENT R, BOU-GHARIOS G, DE VAL S (2013). Analysis of DIl4 regulation reveals a combinatorial role for Sox and Notch in arterial development. Proc Natl Acad Sci USA 110: 11893-11898.

SAKAMOTO Y, HARA K, KANAI-AZUMA M, MATSUI T, MIURA Y, TSUNEKAWA N, KUROHMARU M, SAIJOH Y, KOOPMAN P, KANAI Y (2007). Redundant roles of Sox17 and Sox18 in early cardiovascular development of mouse embryos. Biochem Biophys Res Commun 360: 539-544.

SHALABYF, ROSSANT J, YAMAGUCHITP, GERTSENSTEIN M, WUXF, BREITMAN ML, SCHUH AC (1995). Failure of blood-island formation and vasculogenesis in Flk-1-deficient mice. Nature 376: 62-66.
SHIOZAWA M, HIRAOKA Y, KOMATSU N, OGAWA M, SAKAI Y, AISO S (1996) Cloning and characterization of Xenopus laevis xSox7 cDNA. Biochim Biophys Acta 1309: 73-76.

STOCK DW, BUCHANAN AV, ZHAO Z, WEISS KM (1996). Numerous members of the Sox family of HMG box-containing genes are expressed in developing mouse teeth. Genomics 37: 234-237.

TAKASH W, CAÑIZARES J, BONNEAUD N, POULAT F, MATTÉI MG, JAY P, BERTA $P$ (2001). SOX7 transcription factor: sequence, chromosomal localisation, expression, transactivation and interference with Wnt signalling. Nucleic Acids Res 29: 4274-4283.

TANIGUCHI K, HIRAOKA Y, OGAWA M, SAKAI Y, KIDO S, AISO S (1999). Isolation and characterization of a mouse SRY-related cDNA, mSox7. Biochim Biophys Acta 1445: 225-231.

TAM PP, KHOO PL, WONG N, TSANG TE, BEHRINGER RR (2004). Regionalization of cell fates and cell movement in the endoderm of the mouse gastrula and the impact of loss of Lhx1(Lim1) function. Dev Biol 274: 171-187.

UENO S, WEIDINGER G, OSUGI T, KOHN AD, GOLOB JL, PABON L, REINECKE H, MOON RT, MURRY CE (2007). Biphasic role for Wnt/beta-catenin signaling in cardiac specification in zebrafish and embryonic stem cells. Proc Natl Acad SCi USA 104: 9685-90.

WAT M, GARCIA M, CHEN Y, YU Z, HERNANDEZ A, SCHWARTZ R J, LEE B, DICKINSON M, SCOTT D (2011). Mouse models provide insights into the mechanisms underling abnormal cardiac development associated with recurrent 8p23.1 deletions. 12th International Congress of Human Genetics. The American Society of Human Genetics, 333F (Abstr.)

WAT M, BECK T, HERNANDEZ-GARCIAA, YU Z, VEENMA D, GARCIAM, HOLDER A, WAT J, CHEN Y, MOHILA C, LALLY K, DICKINSON M, TIBBOEL D, DE KLEIN A, LEE B, SCOTT DA (2012). Mouse model reveals the role of SOX7 in the development of congenital diaphragmatic hernia associated with recurrent deletions of 8p23.1. Hum Mol Genet 21: 4115-4125.

WIECH T, NIKOLOPOULOS E, WEIS R, LANGER R, BARTHOLOMÉ K, TIMMER J, WALCH AK, HÖFLER H, WERNER M (2009). Genome-wide analysis of genetic alterations in Barrett's adenocarcinoma using single nucleotide polymorphism arrays. Lab Invest 89: 385-397.

WILSON ME, YANG KY, KALOUSOVA A, LAU J, KOSAKA Y, LYNN FC, WANG J, MREJEN C, EPISKOPOU V, CLEVERS HC, GERMAN MS (2005). The HMG box transcription factor Sox 4 contributes to the development of the endocrine pancreas. Diabetes 54: 3402-3409.

YAMAUCHI F, OKADA M, KATO K, JAKT LM, IWATA H (2007). Array-based functional screening for genes that regulate vascular endothelial differentiation of Flk1-positive progenitors derived from embryonic stem cells. Biochim Biophys Acta 1770: 1085-1097.

YAMAMOTO F, YAMAMOTO M (2008). Identification of genes that exhibit changes in expression on the $8 \mathrm{p}$ chromosomal arm by the Systematic Multiplex RT-PCR (SM RT-PCR) and DNA microarray hybridization methods. Gene Expr 14: 217-227.

YOUNG N, HAHN CN, POH A, DONG C, WILHELM D, OLSSON J, MUSCAT GE, PARSONS P, GAMBLE JR, KOOPMAN P (2006). Effect of disrupted SOX18 transcription factor function on tumor growth, vascularization, and endothelial development. J Natl Cancer Inst 98: 1060-1067.

ZHANG C, BASTA T, FAWCETT SR, KLYMKOWSKY MW (2005a). SOX7 is an immediate-early target of VegT and regulates Nodal-related gene expression in Xenopus. Dev Biol 278: 526-541.

ZHANG C, BASTA T, KLYMKOWSKY MW (2005b). SOX7 and SOX18 are essentia for cardiogenesis in Xenopus. Dev Dyn 234: 878-891.

ZHANG Y, HUANG S, DONG W, LI L, FENG Y, PAN L, HAN Z, WANG X, REN G, SU D, HUANG B, LU J (2009). SOX7, down-regulated in colorectal cancer, induces apoptosis and inhibits proliferation of colorectal cancer cells. Cancer Lett277:29-37.

ZHONG TP, CHILDS S, LEU JP, FISHMAN MC (2001). Gridlock signalling pathway fashions the first embryonic artery. Nature 414: 216-220. 


\section{Further Related Reading, published previously in the Int. J. Dev. Biol.}

Loss of plakophilin 2 disrupts heart development in zebrafish

Miriam A. Moriarty, Rebecca Ryan, Pierce Lalor, Peter Dockery, Lucy Byrnes and Maura Grealy

Int. J. Dev. Biol. (2012) 56: 711-718

http://dx.doi.org/10.1387/ijdb.113390mm

Noggin4 expression during chick embryonic development

Alexander V. Borodulin, Fedor M. Eroshkin, Andrey V. Bayramov and Andrey G. Zaraisky

Int. J. Dev. Biol. (2012) 56: 403-406

http://dx.doi.org/10.1387/ijdb.120020az

Tumor blood vessel visualization

Jeannine Missbach-Guentner, Julia Hunia and Frauke Alves

Int. J. Dev. Biol. (2011) 55: 535-546

http://dx.doi.org/10.1387/ijdb.103229jm

Hematopoietic development in the zebrafish

Elizabeth J. Paik and Leonard I. Zon

Int. J. Dev. Biol. (2010) 54: 1127-1137

http://dx.doi.org/10.1387/ijdb.093042ep

Dissecting hematopoietic differentiation using the embryonic stem cell differentiation model

Tara L. Huber

Int. J. Dev. Biol. (2010) 54: 991-1002

http://dx.doi.org/10.1387/ijdb.103065th

Differential expression of the Brunol/CELF family genes during Xenopus laevis early development Jingyang Wu, Chaocui Li, Shuhua Zhao and Bingyu Mao

Int. J. Dev. Biol. (2010) 54: 209-214

http://dx.doi.org/10.1387/ijdb.082685jw

Expression of Hex during feather bud development

Akiko Obinata and Yoshihiro Akimoto

Int. J. Dev. Biol. (2005) 49: 885-890

http://dx.doi.org/10.1387/ijdb.052037ao

5 yr ISI Impact Factor $(2011)=2.959$

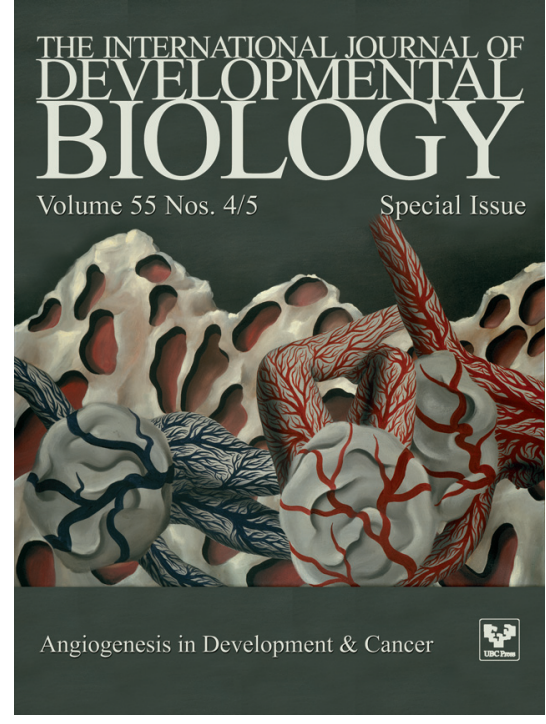

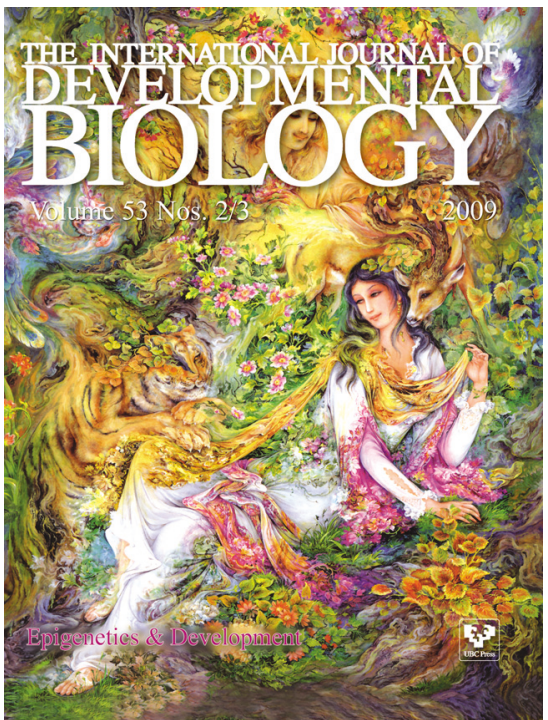

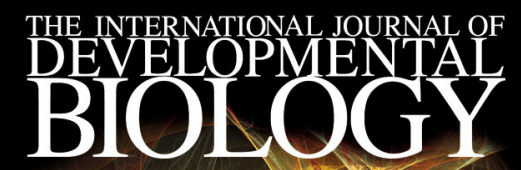

Volume 50 Nos. 2/3 s. Stecial Issue

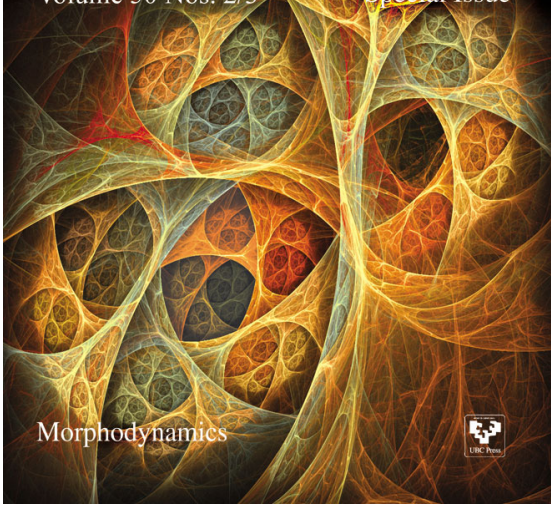

